CLINICAL STUDY

\title{
Maternal testosterone levels during pregnancy are associated with offspring size at birth
}

\author{
S M Carlsen ${ }^{1,2}$, G Jacobsen ${ }^{1}$ and P Romundstad ${ }^{1}$ \\ ${ }^{1}$ Department of Public Health and General Practice, Norwegian University of Science and Technology, N-7489 Trondheim, Norway and ${ }^{2}$ Department of \\ Medicine, Section of Endocrinology, St Olavs Hospital HF, University Hospital of Trondheim, Olav Kyrres gt 17, N-7006 Trondheim, Norway
}

(Correspondence should be addressed to S M Carlsen at St Olavs Hospital HF; Email: sven.carlsen@ntnu.no)

\begin{abstract}
Objective: Animal studies have indicated that maternal androgen levels influence the intrauterine environment and development of the offspring. Human data are missing. We therefore investigated the possible association between maternal androgens and offspring size at birth in humans.

Design: A random sample of parous Caucasian women $(n=147)$ was followed prospectively through pregnancy.

Methods: Maternal serum levels of dehydroepiandrosterone sulfate (DHEAS), androstenedione, testosterone and sex hormone-binding globulin (SHBG) were measured at gestational weeks 17 and 33. The main outcome measures were weight and length at birth. Associations between maternal androgen levels and offspring birth weight and length were investigated using multiple linear regression modeling adjusted for potential confounding by maternal height, pre-pregnancy body mass index, smoking, parity, offspring gender and gestational age at birth.

Results: Elevated maternal testosterone levels at week 17 and 33 were both associated with lower birth weights and lengths. Accordingly, at week 17, an increase in maternal testosterone levels from the 25 th to the 75 th percentile was associated with a decrease in birth weight by $160 \mathrm{~g}$ (95\% confidence interval (CI); 29-290 g), while at week 33 that estimate was 115 g (95\% CI; 21-207 g). No similar associations were observed for DHEAS, androstenedione or SHBG.

Conclusions: Elevated maternal testosterone levels during human pregnancy are associated with growth restriction in utero. Our results support animal studies, which have indicated that maternal androgen levels influence intrauterine offspring environment and development.
\end{abstract}

European Journal of Endocrinology 155 365-370

\section{Introduction}

Low birth weight (LBW) has been associated with increased risk of cardiovascular and metabolic diseases in adult life. Epidemiologic studies have reported inverse associations between birth weight and systolic blood pressure (1-3), blood lipids (4), adiposity (5), stroke (6) and cardiovascular disease and mortality $(1,7,8)$. Moreover, it has been repeatedly documented that birth weight is inversely related to insulin resistance $(9,10)$, subsequent risk of type 2 diabetes $(9,11)$ and other characteristics of the metabolic or insulin resistance syndrome $(3,9,12)$.

Although these findings support the 'fetal origins hypothesis' - that susceptibility to these chronic adult conditions may be programmed in utero - the understanding of the underlying mechanism(s) is still meager $(9,13)$. One possible mechanism involves the capacity of insulin secretion later in life (14-16). Another one is that lasting fetal metabolic changes lead to insulin resistance in adult life. In humans, reduced birth weight is associated with later-increased insulin resistance rather than with reduced $\beta$-cell function (9).

In the prenatally androgenised rhesus monkeys, female fetuses exposed to testosterone in early gestational life showed impaired insulin secretion in adult life, while those which were exposed later showed decrements in insulin sensitivity, preserved insulin secretory function and increased adiposity (16). Further, prenatally androgenised male rhesus monkeys also developed insulin resistance and impaired insulin secretion (17). In ewes, prenatal testosterone exposure caused intrauterine growth retardation (18). A recent review of animal data indicates that excess fetal androgen exposure can induce metabolic and endocrine deficits in females, possibly by an adverse, permanent programming of the metabolic pathways (19).

Reduced insulin sensitivity, decreased insulin secretion and adiposity during gestation are associated with reduced birth size $(5,9,10)$. Hence, we tested the hypothesis that in humans, endogenous maternal circulating androgen levels are negatively associated 
with birth size of the offspring. We used data from a prospective multicenter study that were originally designed to investigate causes and consequences of being born small for gestational age (SGA) in Scandinavia.

\section{Subjects and methods}

\section{Subjects}

The study was based on the Scandinavian part of an international multicenter study initiated and financed by the US National Institute of Child Health and Human Development (NIHCD). This was a prospective study with an aim to identify causes and consequences of being born SGA. The design of the study has been published in detail elsewhere (20). Briefly, Scandinavian participants were recruited between 1 January 1986 and 31 March 1988 at the university hospitals in Trondheim and Bergen (Norway) and Uppsala (Sweden). Para 1 and para 2 women of Caucasian origin who spoke one of the Scandinavian languages were included. A total of 6354 pregnant women were invited to participate and 5722 women with singleton pregnancies responded and were included at one of the study sites before gestational week 20. Among these women, two groups were followed up in detail at weeks 17, 25, 33 and 37 of pregnancy and at birth. The first group consisted of a random sample of $10 \%$ of women included in the study $(n=561)$, while the other $(n=1384)$ consisted of women with one or more defined risk factors for giving birth to SGA child. All the 147 participants of the present subset were selected at random from the $10 \%$ random sample of pregnant women.

\section{Clinical protocol}

The detailed follow-up during pregnancy included questionnaires and clinical evaluation of the mother with blood pressure and ultrasound measurements and urinary and blood samples. The expected date of delivery was based on menstrual history. In cases where the last menstrual period (LMP) was unknown or if LMP and ultrasound dates differed by more than \pm 14 days, the term was based on routine ultrasonography at week 17 . Information about maternal age, smoking habits and pre pregnancy weight was collected at the beginning of the study. At birth, the infants were weighed to the nearest $10 \mathrm{~g}$ on a standard scale and birth length to the nearest centimeter $(\mathrm{cm})$. The regional committee for medical research ethics in each of the study sites approved the study and a signed informed consent was obtained from all the participants.

\section{Analytical methods}

Non-fasting serum samples were drawn during working hours (mainly during the morning) and centrifuged at room temperature within $60 \mathrm{~min}$. Before the assays were performed, serum was stored in screw-capped vials at $-80{ }^{\circ} \mathrm{C}$ for a mean of 12 years (11-13 years). Dehydroepiandrosterone sulfate (DHEAS) and sex hormone-binding globulin (SHBG) were measured using competitive immunoassay on the Immulite 2000 analyzer using the reagents and calibrators delivered by the supplier (Diagnostic Products Corporation, Los Angeles, CA, USA). The lower detection limits for DHEAS and SHBG were $0.054 \mu \mathrm{mol} / \mathrm{l}$ and $0.2 \mathrm{nmol} / \mathrm{l}$ respectively. Testosterone and androstenedione were measured using RIA technique with reagents and calibrators delivered by Orion Diagnostica, Espoo, Finland (testosterone) and Diagnostic Products Corporation (androstenedione). The lower detection limits for testosterone and androstenedione were 0.1 and $0.14 \mathrm{nmol} / \mathrm{l}$ respectively.

\section{Statistical analysis}

We used linear multiple regression analyses to assess the concurrent contribution to birth size for each measured factor, after adjustment for well-known predictors associated with intrauterine growth. They were maternal height, pre pregnancy body mass index (BMI), smoking, parity, offspring gender and gestational age at birth. Pearson statistics were used to correlate androgen levels measured at different time points during pregnancy. All the statistical procedures were performed by the use of SPSS for Windows, version 13.0 (SPSS Inc., Chicago, IL, USA).

\section{Results}

Maternal characteristics, distribution of androgen levels during pregnancy and birth characteristics are given in Table 1.

In multiple linear regression models, we observed significant associations between maternal levels of testosterone and birth weight (Table 2) and birth length (Table 3) corrected for maternal age, height, pre pregnancy BMI, smoking during pregnancy, parity, offspring gender and gestational age at birth. An increase in maternal testosterone of $1 \mathrm{nmol} / \mathrm{l}$ at gestational week 17 was associated with a decrease in birth weight of $133 \mathrm{~g}$ (95\% confidence interval (CI); $24-242 \mathrm{~g}$ ) and a decrease in birth length of $0.6 \mathrm{~cm}$ $(95 \%$ CI; $0.2-1.1 \mathrm{~cm})$. Thus, an increase in maternal testosterone levels at week 17 from the 25th to the 75th percentile was associated with a decrease in birth weight of $160 \mathrm{~g} \mathrm{(95 \%} \mathrm{CI;} \mathrm{29-290} \mathrm{g)} \mathrm{and} \mathrm{birth} \mathrm{length} \mathrm{of}$ $0.8 \mathrm{~cm}(95 \%$ CI; $0.2-1.3 \mathrm{~cm})$. At week 33 , the corresponding estimates were $115 \mathrm{~g}(95 \% \mathrm{CI} ; 21-$ $207 \mathrm{~g})$ and $0.5 \mathrm{~cm}(95 \% \mathrm{CI} ; 0.1-0.8 \mathrm{~cm})$. No similar associations were observed for DHEAS, androstenedione or SHBG. Leaving testosterone out of the multivariate models did not materially change the effect of 
Table 1 Maternal characteristics, distribution of androgen levels during pregnancy and birth characteristics of the study population.

\begin{tabular}{|c|c|c|c|c|c|c|c|c|c|}
\hline Variable & & $n$ & Mean & (s.D.) & Minimum & 25th percentile & Median & 75th percentile & Maximum \\
\hline DHEAS $(\mu \mathrm{mol} / \mathrm{l})$ & $\begin{array}{l}\text { Week } 17 \\
\text { Week } 33\end{array}$ & $\begin{array}{l}147 \\
141\end{array}$ & $\begin{array}{l}2.9 \\
2.2\end{array}$ & $\begin{array}{l}(1.4) \\
(1.2)\end{array}$ & $\begin{array}{l}0.5 \\
0.4\end{array}$ & $\begin{array}{l}1.9 \\
1.4\end{array}$ & $\begin{array}{l}2.8 \\
2.1\end{array}$ & $\begin{array}{l}3.6 \\
2.8\end{array}$ & $\begin{array}{l}8.2 \\
7.7\end{array}$ \\
\hline $\begin{array}{l}\text { Androstenedione } \\
(\mathrm{nmol} / \mathrm{l})\end{array}$ & $\begin{array}{l}\text { Week } 17 \\
\text { Week } 33\end{array}$ & $\begin{array}{l}147 \\
143\end{array}$ & $\begin{array}{l}10.6 \\
16.7\end{array}$ & $\begin{array}{l}(4.5) \\
(7.0)\end{array}$ & $\begin{array}{l}2.3 \\
5.8\end{array}$ & $\begin{array}{r}7.6 \\
12.1\end{array}$ & $\begin{array}{r}9.8 \\
15.2\end{array}$ & $\begin{array}{l}12.4 \\
19.0\end{array}$ & $\begin{array}{l}27.3 \\
49.0\end{array}$ \\
\hline $\begin{array}{l}\text { Testosterone } \\
(\mathrm{nmol} / \mathrm{l})\end{array}$ & $\begin{array}{l}\text { Week } 17 \\
\text { Week } 33\end{array}$ & $\begin{array}{l}147 \\
144\end{array}$ & $\begin{array}{l}2.0 \\
2.6\end{array}$ & $\begin{array}{l}(1.0) \\
(1.8)\end{array}$ & $\begin{array}{l}0.5 \\
0.9\end{array}$ & $\begin{array}{l}1.4 \\
1.6\end{array}$ & $\begin{array}{l}1.8 \\
2.2\end{array}$ & $\begin{array}{l}2.6 \\
3.0\end{array}$ & $\begin{array}{r}7.2 \\
14.5\end{array}$ \\
\hline SHBG $(\mathrm{nmol} / \mathrm{l})$ & $\begin{array}{l}\text { Week } 17 \\
\text { Week } 33\end{array}$ & $\begin{array}{l}147 \\
145\end{array}$ & $\begin{array}{l}320 \\
366\end{array}$ & $\begin{array}{l}(77) \\
(81)\end{array}$ & $\begin{array}{l}166 \\
167\end{array}$ & $\begin{array}{l}266 \\
316\end{array}$ & $\begin{array}{l}315 \\
362\end{array}$ & $\begin{array}{l}361 \\
412\end{array}$ & $\begin{array}{l}593 \\
580\end{array}$ \\
\hline Smoking (yes/no) & $\begin{array}{l}\text { Week } 17 \\
\text { Week } 33\end{array}$ & $\begin{array}{l}46 / 101 \\
43 / 104\end{array}$ & $\begin{array}{l}- \\
-\end{array}$ & $\begin{array}{l}- \\
-\end{array}$ & $\begin{array}{l}- \\
-\end{array}$ & $\begin{array}{l}- \\
-\end{array}$ & $\begin{array}{l}- \\
-\end{array}$ & $\begin{array}{l}- \\
-\end{array}$ & $\begin{array}{l}- \\
-\end{array}$ \\
\hline $\begin{array}{l}\text { Number of previous } \\
\text { births }(1 / 2)\end{array}$ & & $102 / 45$ & - & - & - & - & - & - & - \\
\hline $\begin{array}{l}\text { Offspring gender } \\
\text { (male/female) }\end{array}$ & & $75 / 72$ & - & - & - & - & - & - & - \\
\hline $\begin{array}{l}\text { Maternal age } \\
\text { (years) }\end{array}$ & & 147 & 29 & (4) & 18 & 26 & 28 & 31 & 39 \\
\hline Maternal height $(\mathrm{cm})$ & & 147 & 167 & (6) & 152 & 162 & 166 & 171 & 182 \\
\hline $\begin{array}{l}\text { Pre pregnancy BMI } \\
\left(\mathrm{kg} / \mathrm{m}^{2}\right)\end{array}$ & & 147 & 21.8 & $(2.4)$ & 17.6 & 20.1 & 21.3 & 23.2 & 32.7 \\
\hline $\begin{array}{l}\text { Gestational age at } \\
\text { birth (days) }\end{array}$ & & 147 & 280 & (9) & 250 & 274 & 280 & 286 & 298 \\
\hline Birth weight (g) & & 147 & 3660 & $(490)$ & 2000 & 3380 & 3630 & 3940 & 5450 \\
\hline
\end{tabular}

DHEAS, dehydroepiandrosterone sulfate; SHBG, sex hormone-binding globulin.

Table 2 Multivariable linear regression of birth weight (grams) according to maternal androgen levels at weeks 17 and 33 adjusted for maternal and fetal factors.

\begin{tabular}{|c|c|c|c|c|c|c|}
\hline Covariate & Coefficient & $\begin{array}{l}\text { Week } 17 \\
95 \% \mathrm{Cl}\end{array}$ & P-value & Coefficient & $\begin{array}{r}\text { Week } 33 \\
95 \% \mathrm{Cl}\end{array}$ & $P$-value \\
\hline \multicolumn{7}{|l|}{ Study center } \\
\hline Trondheim* & 0 & & & 0 & & \\
\hline Bergen & 112 & ( -48 to 272$)$ & 0.2 & 84 & $(-69$ to 237$)$ & 0.3 \\
\hline Uppsala & 79 & ( -89 to 247$)$ & 0.4 & -20 & $(-180$ to 140$)$ & 0.8 \\
\hline $\begin{array}{l}\text { Number of previous births } \\
\text { (number) } \dagger\end{array}$ & 57 & $(-92$ to 206$)$ & 0.5 & 31 & $(-114$ to 177$)$ & 0.7 \\
\hline $\begin{array}{l}\text { Mother's age at study entry } \\
\text { (years) } \dagger\end{array}$ & 5 & $(-13$ to 24$)$ & 0.6 & 1 & $(-18$ to 20$)$ & 0.9 \\
\hline Mother's height $(\mathrm{cm}) \dagger$ & 25 & (14 to 36$)$ & $<0.001$ & 21 & (10 to 32 ) & $<0.001$ \\
\hline Pre pregnancy BMI $\left(\mathrm{kg} / \mathrm{m}^{2}\right) \dagger$ & 56 & (29 to 84 ) & $<0.001$ & 49 & (22 to 76 ) & $<0.001$ \\
\hline \multicolumn{7}{|l|}{ Smoking } \\
\hline Non-smoking* & 0 & & & 0 & & \\
\hline Smoking & -124 & $(-268$ to 20$)$ & 0.09 & -138 & $(-286$ to 10$)$ & 0.07 \\
\hline \multicolumn{7}{|l|}{ Offspring gender } \\
\hline Male $^{*}$ & 0 & & & 0 & & \\
\hline Female & -160 & $(-295$ to -26$)$ & 0.02 & -172 & $(-303$ to -40$)$ & 0.01 \\
\hline Gestational age at birth (days) $\dagger$ & 18 & (12 to 25$)$ & $<0.001$ & 20 & $(13$ to 26$)$ & $<0.001$ \\
\hline DHEAS $(\mu \mathrm{mol} / /)$ & -24 & $(-79$ to 32$)$ & 0.4 & -25 & $(-87$ to 37$)$ & 0.4 \\
\hline Androstenedione $(\mathrm{nmol} / \mathrm{l}) \dagger$ & 19 & $(-10$ to 47$)$ & 0.2 & 4 & $(-15$ to 23$)$ & 0.7 \\
\hline SHBG $(\mathrm{nmol} / \mathrm{l}) \dagger$ & 1 & (0 to 1 ) & 0.2 & 0 & $(-1$ to 1$)$ & 0.7 \\
\hline Testosterone $(\mathrm{nmol} / \mathrm{l}) \dagger$ & -133 & $(-242$ to -24$)$ & 0.02 & -82 & $(-148$ to -15$)$ & 0.02 \\
\hline
\end{tabular}

$\mathrm{Cl}$, confidence interval; DHEAS, dehydroepiandrosterone sulfate; SHBG, sex hormone-binding globulin.

*Baseline category.

† Per unit. 
Table 3 Multivariable linear regression of birth length $(\mathrm{cm})$ according to maternal androgen levels at gestational weeks 17 and 33 adjusted for maternal and fetal factors.

\begin{tabular}{|c|c|c|c|c|c|c|}
\hline Covariate & Coefficient & $\begin{array}{c}\text { Week } 17 \\
95 \% \mathrm{Cl}\end{array}$ & $P$-value & Coefficient & $\begin{array}{l}\text { Week } 33 \\
95 \% \mathrm{Cl}\end{array}$ & $P$-value \\
\hline \multicolumn{7}{|l|}{ Study center } \\
\hline Trondheim* ${ }^{*}$ & 0 & & & 0 & & \\
\hline Bergen & 0.9 & $(0.2$ to 1.5$)$ & 0.009 & 0.8 & $(0.1$ to 1.4$)$ & 0.02 \\
\hline Uppsala & 0.7 & $(0.0$ to 1.4$)$ & 0.04 & 0.4 & $(-0.2$ to 1.1$)$ & 0.2 \\
\hline Number of previous births (number) $\dagger$ & -0.2 & $(-0.8$ to 0.4$)$ & 0.5 & -0.3 & $(-0.9$ to 0.3$)$ & 0.3 \\
\hline Mother's age at study entry (years) $\dagger$ & 0.1 & $(0.0$ to 0.2$)$ & 0.06 & 0.1 & $(0.0$ to 0.1$)$ & 0.1 \\
\hline Mother's height $(\mathrm{cm}) \dagger$ & 0.1 & $(0.1$ to 0.1$)$ & $<0.001$ & 0.1 & $(0.0$ to 0.1$)$ & 0.001 \\
\hline Pre pregnancy BMI $\left(\mathrm{kg} / \mathrm{m}^{2}\right) \dagger$ & 0.2 & $(0.1$ to 0.3$)$ & 0.005 & 0.1 & $(0.0$ to 0.2$)$ & 0.02 \\
\hline \multicolumn{7}{|l|}{ Smoking } \\
\hline Non-smoking* & 0 & & & 0 & & \\
\hline Smoking & -0.3 & $(-0.9$ to 0.3$)$ & 0.3 & -0.2 & $(-0.8$ to 0.4$)$ & 0.5 \\
\hline \multicolumn{7}{|l|}{ Offspring gender } \\
\hline Male $^{*}$ & 0 & & & 0 & & \\
\hline Female & -1.0 & $(-1.5$ to -0.4$)$ & 0.001 & -1.0 & $(-1.5$ to -0.4$)$ & $<0.001$ \\
\hline Gestational age at birth (days) & 0.1 & $(0.0$ to 0.1$)$ & $<0.001$ & 0.1 & $(0.0$ to 0.1$)$ & $<0.001$ \\
\hline DHEAS ( $\mu \mathrm{mol} / \mathrm{l})$ & 0.1 & $(-0.2$ to 0.3$)$ & 0.6 & 0.1 & $(-0.2$ to 0.3$)$ & 0.5 \\
\hline Androstenedione $(\mathrm{nmol} / \mathrm{l}) \dagger$ & 0.1 & $(-0.1$ to 0.2$)$ & 0.2 & 0.0 & $(-0.1$ to 0.1$)$ & 1.0 \\
\hline SHBG $(\mathrm{nmol} / \mathrm{l})+$ & 0.0 & $(0.0$ to 0.0$)$ & 0.3 & 0.0 & $(0.0$ to 0.0$)$ & 0.7 \\
\hline Testosterone $(\mathrm{nmol} / \mathrm{l}) \dagger$ & -0.6 & $(-1.1$ to -0.2$)$ & 0.006 & -0.3 & $(-0.6$ to -0.1$)$ & 0.01 \\
\hline
\end{tabular}

$\mathrm{Cl}$, confidence interval; DHEAS, dehydroepiandrosterone sulfate; SHBG, sex hormone-binding globulin.

*Baseline category.

†Per unit.

androstenedione or any of the other risk factors on offspring size at birth (data not shown).

Significant associations between levels at pregnancy week 17 and 33 were seen for androstenedione $(r=0.80 ; P<0.0005)$, DHEAS $(r=0.69 ; P<0.0005)$, testosterone $(r=0.75 ; P<0.0005)$ and SHBG $(r=0.71$; $P<0.0005)$.

\section{Discussion}

This study presents human data that show the associations between increasing circulating endogenous maternal testosterone levels during pregnancy and a decrease in offspring birth weight and length in a random selection of pregnant women. This inverse association remained unchanged after correction of several well-known factors associated with intrauterine growth. At gestational week 17, an increase in circulating maternal testosterone levels from the 25 th to the 75 th percentile corresponded to a decrease in birth weight of $160 \mathrm{~g}$. This weight difference is similar to the impact that traditional factors such as fetal gender or maternal smoking have on birth weight.

Newborn size characteristics are important predictors of a multitude of disorders in adult life (1-12). Hence, our identification of elevated maternal testosterone levels as a new indicator of intrauterine growth restriction in humans is important as it opens up the possibility to better understand the mechanisms involved in intrauterine growth. This in turn, may help to elucidate the mechanism(s) behind the 'fetal origins hypothesis' $(9,13)$.
Our findings are supported by animal data. For instance, in sheep, testosterone treatment of the mother during early to mid pregnancy reduced birth weight and height in the offspring of either gender (21). This supports the concept that fetal growth retardation, an early marker of adult diseases, can be initiated through prenatal excess exposure to sex steroids. Studies in nonhuman primates and other animals have shown that prenatal exposure to testosterone led to female hyperandrogenism (19), infertility $(22,23)$, behavior modifications (24) abdominal adiposity (25) and insulin resistance (17) during adulthood in the offspring. In all these studies, testosterone was administered to otherwise normal pregnant female animals and hence the increase in circulating maternal testosterone was of exogenous origin and not caused by any maternal disease.

There are also some human data that support both our findings and animal data. Women with polycystic ovary syndrome (PCOS) have ovaries with multiple cysts, menstrual disturbances and hyperandrogenism. Sir-Peterman reported that in PCOS women, maternal androgen levels are increased even in the pregnant state (26). Recently, the same authors published a study that showed a marked increase in the prevalence of SGA births in PCOS mothers compared with control pregnancies $(12.8 \%$ vs $2.8 \%)$. In contrast, the prevalence of large for gestational age births (LGA) were the same in both groups (27). On the other hand, others did or did not find a gender-specific decrease of birth weight in offspring of PCOS women $(28,29)$.

Maternal testosterone levels can affect newborn growth and size through several potential mechanisms. Maternal testosterone may modify her energy 
homeostasis and thus decrease nutrient supplies to the placenta and fetus. Alternatively, testosterone may modify placental function and reduce the capacity for transport of nutrients to the fetus. Maternal testosterone may also cross the placenta and exert a direct effect on fetal growth and/or energy homeostasis. A combination of all these mechanisms is also conceivable.

We investigated the effect of circulating endogenous androgens in a random sample of pregnant para 1 and para 2 women. The observed inverse association between circulating maternal testosterone levels and fetal growth may arise from any mechanism affecting fetal growth. Accordingly, maternal testosterone may only be a biomarker for fetal growth. However, assisted by the available animal data on the effect of the exertion of exogenously administered testosterone on otherwise normal pregnancies (19), we hypothesize that the association between maternal testosterone levels and reduced birth size is a direct effect of increased maternal androgen levels. Probably, it is mediated by one or more of the above possible mechanisms and is not just a chance-coincidental phenomenon. Testosterone is a liposoluble steroid and one may expect it to cross the placenta readily. This view is supported by a human study, which showed a second trimester association between maternal and fetal circulating testosterone levels. However, these were not normal pregnancies (30).

According to the 'fetal origin hypothesis', intrauterine programming is an adaptive response to fetal malnutrition in utero. In the developing world, this is mostly due to maternal malnutrition. In contrast, in the industrialized world, it is mainly considered to result from placental dysfunction, which in turn results in a reduced supply of nutrients to the fetus in an otherwise well-nourished mother (13). However, the molecular mechanism(s) involved in that process has not been clearly identified.

We observed that the effect on birth size of maternal testosterone levels tended to be more pronounced in the second than in the third trimester. In animals, it is well established that the hormonal status of the fetus during certain stages of gestation is crucial for its growth and development (24). Also, in non-human primates, testosterone exposure in early and late pregnancy tends to affect the offspring differently (16).

It has been shown in the rat that maternal treatment with androstenedione affected offspring health in a similar way to that of testosterone (31). Still, we found that testosterone, but not androstenedione, was associated with size at birth. This was also the case when testosterone was omitted from the multivariable models. A possible explanation for this is that androstenedione is a weaker androgen, which may also be converted to testosterone before it exerted its adverse effect in the rat model.

In the present study, blood samples were drawn in the non-fasting state during different times of the day and stored at a mean of 12 years before the analyses. This might have increased the variability of testosterone levels and could be considered a weakness of the present study. However, the high association of steroid levels at pregnancy weeks 17 and 33 is not compatible with this being a major objection to the study. On the contrary, it can be argued that since we were able to show a statistical association, the biological association between testosterone levels and birth measures may be even stronger than the statistical relations we found. It further adds to the strengths of the present study that testosterone levels were related to size at birth both in the early second and mid third trimester. Also, we adjusted four maternal factors with strong and wellknown prognostic properties for birth size. Still the possibility that our results are a consequence of unidentified confounding effects remains. With these limitations, we propose that maternal testosterone level emerges as a novel, independent predictor of prenatal growth deviations.

In conclusion, this study relates human maternal testosterone levels during pregnancy with offspring size at birth after control of traditional factors known to be related to birth size. The present data support animal studies that have indicated that maternal androgen exposure may influence the intrauterine environment and thereby offspring development. Further studies should aim to confirm or negate our findings and try to elucidate whether or not androgens are part of a causal pathway.

\section{Acknowledgements}

We wish to thank Morten Lindberg, MD, and Professor Kristian S Bjerve, Department of Clinical Chemistry, St Olavs Hospital, University Hospital of Trondheim, Norway for performing the biochemical analyses.

\section{Funding}

The study was supported by the US National Institutes of Child Health and Human Development (NICHD Contract No. 1-HD-4-2803) and grants from Glaxo Wellcome AS, Norway and Sintef Unimed Research Foundation, Trondheim, Norway.

\section{References}

1 Barker DJ, Osmond C, Golding J, Kuh D \& Wadsworth ME. Growth in utero, blood pressure in childhood and adult life, and mortality from cardiovascular disease. British Medical Journal 1989298 564-567.

2 Barker DJ. Foetal origins of coronary heart disease. British Medical Journal 1995311 171-174.

3 Fall CH, Osmond C, Barker DJ, Clark PM, Hales CN, Stirling Y \& Meade TW. Foetal and infant growth and cardiovascular risk factors in women. British Medical Journal $1995310428-432$.

4 Lauren L, Jarvelin MR, Elliott P, Sovio U, Spellman A, McCarthy M, Emmett P, Rogers I, Hartikainen AL, Pouta A, Hardy R, Wadsworth M, Helmsdal G, Olsen S, Bakoula C, Lekea V \& 
Millwood I, on behalf of the EURO-BLCS Study Group. Relationship between birthweight and blood lipid concentrations in later life: evidence from the existing literature. International Journal of Epidemiology 200332 862-876.

5 Gale CR, Martyn CN, Kellingray S, Eastell R \& Cooper C. Intrauterine programming of adult body composition. Journal of Clinical Endocrinology and Metabolism 200186 267-272.

6 Rich-Edwards JW, Kleinman K, Michels KB, Stampfer MJ, Manson JE, Rexrode KM, Hibert EN \& Willett WC. Longitudinal study of birth weight and adult body mass index in predicting risk of coronary heart disease and stroke in women. British Medical Journal $20053301115-1120$.

7 Forsen T, Eriksson JG, Tuomilehto J, Osmond C \& Barker DJ. Growth in utero and during childhood among women who develop coronary heart disease: longitudinal study. British Medical Journal 1999319 1403-1407.

8 Barker DJ, Winter PD, Osmond C, Margetts B \& Simmonds SJ. Weight in infancy and death from ischaemic heart disease. Lancet 19892 577-580.

9 Newsome CA, Shiell AW, Fall CH, Phillips DI, Shier R \& Law CM. Is birth weight related to later glucose and insulin metabolism? A systematic review. Diabetic Medicine 200320 339-348.

10 Eriksson JG, Forsen T, Tuomilehto J, Jaddoe VW, Osmond C \& Barker DJ. Effects of size at birth and childhood growth on the insulin resistance syndrome in elderly individuals. Diabetologia 200245 342-348.

11 Forsen T, Eriksson J, Tuomilehto J, Reunanen A, Osmond C \& Barker D. The foetal and childhood growth of persons who develop type 2 diabetes. Annals of Internal Medicine $2000133176-182$.

12 Mi J, Law C, Zhang KL, Osmond C, Stein C \& Barker D. Effects of infant birthweight and maternal body mass index in pregnancy on components of the insulin resistance syndrome in China. Annals of Internal Medicine 2000132 253-260.

13 Ozanne SE. Metabolic programming in animals. British Medical Bulletin 200160 143-152.

14 Garofano A, Cernichow P \& Bréant B. In utero undernutrition impairs rat beta-cell development. Diabetologia $1997 \mathbf{4 0}$ 1231-1234.

15 Garofano A, Cernichow P \& Bréant B. Effect of ageing on beta cell mass and function in rats malnourished during the perinatal period. Diabetologia 199942 711-718.

16 Eisner JR, Dumesic DA, Kemnitz JW \& Abbott DH. Timing of prenatal androgen excess determines differential impairment in insulin secretion and action in adult female rhesus monkeys. Journal of Clinical Endocrinology and Metabolism 200085 1206-1210.

17 Bruns CM, Baum ST, Colman RJ, Eisner JR, Kemnitz JW, Weindruch R \& Abbott DH. Insulin resistance and impaired insulin secretion in prenatally androgenized male rhesus monkeys. Journal of Clinical Endocrinology and Metabolism 2004 89 6218-6223.

18 Steckler T, Wang J, Bartol FF, Roy SK \& Padmanabhan V. Fetal programming: prenatal testosterone treatment causes intrauterine growth retardation, reduces ovarian reserve and increases ovarian follicular recruitment. Endocrinology $2005 \mathbf{1 4 6}$ 3185-3193.

19 Abbott DH, Barnett DK, Bruns CM \& Dumesic DA. Androgen excess fetal programming of female reproduction: a developmental aetiology for polycystic ovary syndrome? Human Reproduction Update $200511357-374$.
20 Bakketeig LS, Jacobsen G, Hoffman HJ, Lindmark G, Bergsjø P, Molne K \& Rodsten J. Pre-pregnancy risk factors of small-forgestational age births among parous women in Scandinavia. Acta Obstetricia et Gynecologica Scandinavica 199372 273-279.

21 Manikkam M, Crespi EJ, Doop DD, Herkimer C, Lee JS, Yu S, Brown MB, Foster DL \& Padmanabhan V. Fetal programming: prenatal testosterone excess leads to fetal growth retardation and postnatal catch-up growth in sheep. Endocrinology 2004145 790-798.

22 Robinson JE, Birch RA, Foster DL \& Padmanabhan V. Prenatal exposure of the ovine fetus to androgens sexually differentiates the steroid feedback mechanisms that control gonadotropin releasing hormone secretion and disrupts ovarian cycles. Archives of Sexual Behavior 200231 35-41.

23 Birch RA, Padmanabhan V, Foster DL, Unsworth WP \& Robinson JE. Prenatal programming of reproductive neuroendocrine function: fetal androgen exposure produces progressive disruption of reproductive cycles in sheep. Endocrinology $2003 \mathbf{1 4 4}$ 1426-1434.

24 Wolf CJ, Hotchkiss A, Ostby JS, LeBlanc GA \& Gray LE, Jr. Effects of prenatal testosterone propionate on the sexual development of male and female rats: a dose-response study. Toxicological Sciences $20026571-86$.

25 Eisner JR, Dumesic DA, Kemnitz JW, Colman RJ \& Abbott DH. Increased adiposity in female rhesus monkeys exposed to androgen excess during early gestation. Obesity Research 2003 $11279-286$.

26 Sir-Petermann T, Maliqueo M, Angel B, Lara HE, Perez-Bravo F \& Recabarren SE. Maternal serum androgens in pregnant women with polycystic ovarian syndrome: possible implications in prenatal androgenization. Human Reproduction $2002 \mathbf{1 7}$ 2573-2579.

27 Sir-Petermann T, Hitchsfeld C, Maliqueo M, Codner E, Echiburu B, Gazitua R, Recabarren S \& Cassorla F. Birth weight in offspring of mothers with polycystic ovarian syndrome. Human Reproduction $2005202122-2126$.

28 Turhan NO, Seckin NC, Aybar F \& Inegol I. Assessment of glucose tolerance and pregnancy outcome of polycystic ovary patients. International Journal of Gynaecology and Obstetrics $2003 \mathbf{8 1}$ 163-168.

29 Glueck CJ, Goldenberg N, Pranikoff J, Loftspring M, Sieve L \& Wang P. Height, weight, and motor-social development during the first 18 months of life in 126 infants born to 109 mothers with polycystic ovary syndrome who conceived on and continued metformin through pregnancy. Human Reproduction 200419 1323-1330.

30 Gitau R, Adams D, Fisk NM \& Glover V. Fetal plasma testosterone correlates positively with cortisol. Archives of Disease in Childhood. Fetal and Neonatal Edition 200590 F166-F169.

31 McGivern RF, Fatayerji N \& Handa RJ. Androstenedione synergizes with stress or prenatal drug exposure to retard fetal growth: role of IGF. Pharmacology, Biochemistry, and Behavior 199655 549-557.

Received 25 January 2006

Accepted 3 May 2006 